\author{
TADEUSZ BOCHEŃSKI \\ Uniwersytet Szczeciński, Polska \\ University of Szczecin, Poland
}

\title{
Przemyst w portach morskich regionu Morza Bałtyckiego
}

\section{Industry in Seaports in the Baltic Sea Region}

Streszczenie: Artykuł nawiązuje do badań nad uprzemysłowieniem portów. Współcześnie poza branżą offshore temat ten nie był szerzej poruszany w literaturze. Celem badań było sprawdzenie, jaka jest struktura branżowa zakładów produkcyjnych niezwiązanych ściśle z gospodarką morską, działających w portach morskich regionu Morza Bałtyckiego oraz próba oceny roli transportu morskiego w obsłudze poszczególnych zakładów. Z analizy wyłączono budownictwo morskie i okrętowe, w tym stocznie produkcyjne i remontowe oraz porty rybackie ze względu na ich specyfikę produkcyjną. Obszar badań to region Morza Bałtyckiego rozumiany jako dziewięć państw: Niemcy, Polska, Litwa, Łotwa, Estonia, Rosja, Finlandia, Szwecja, Dania. Wyróżnić można porty przemysłowe, które stanowią części portów handlowych lub samodzielne porty stanowiące ważne ogniwo w przemysłowym łańcuchu produkcyjnym. Na badanym obszarze funkcjonowało około 270 portów przeładunkowych, z czego 2/5 miało znaczenie przemysłowe. Scharakteryzowano rodzaje przemysłu występujące w badanych ośrodkach portowych oraz uwarunkowania wykorzystania portów na potrzeby zlokalizowanych w nich zakładów przemysłowych. W strukturze zidentyfikowanych zakładów największą grupę stanowił przemysł drzewno-papierniczy, znaczna liczba zakładów reprezentowała także branże energetyczną, mineralną i metalurgiczną. Dostęp do transportu morskiego ma kluczowe znaczenie dla sektora paliwowo-energetycznego - stanowił on jedyną lub główną drogę dostaw surowców do produkcji dla części rafinerii i elektrowni.

Abstract: The article refers to research on the industrialisation of ports. Nowadays, apart from the offshore industry, this topic was not discussed in more detail in the literature. The aim of the study was to check the structure of production plants not closely related to maritime economy which operate in seaports of the Baltic Sea Region and to evaluate the role of maritime transport in servicing individual plants. The analysis excluded maritime construction and shipbuilding (production and repair yards), as well as fishing ports due to their specificity in production. The research area covered the Baltic Sea Region understood as 9 countries: Germany, Poland, Lithuania, Latvia, Estonia, Russia, Finland, Sweden, Denmark. We can distinguish industrial ports that are part of commercial ports or independent ports that are an important link in the industrial production chain. There were about 270 transhipment ports in the study area, two fifths of which were of industrial importance. The types of industry appearing in the surveyed port centres, as well as the conditions of using ports for the needs of industrial plants located in them were characterised. In the structure of the identified plants, the largest group was the wood and paper industry, a significant number of plants also represented the following industries: energy, mineral and metallurgy. Access to maritime transport is crucial for the fuel and energy sector - it was the only or main route for the supply of raw materials for production for a part of refineries and power plants. 
Słowa kluczowe: porty morskie; porty przemysłowe; przemysł w portach; region Morza Bałtyckiego Keywords: Baltic Sea Region; industrial ports; industry in seaports; seaports

Otrzymano: 19 grudnia 2018

Received: 19 December 2018

Zaakceptowano: 3 lipca 2019

Accepted: 3 July 2019

Sugerowana cytacja / Suggested citation:

Bocheński, T. (2019). Przemysł w portach morskich regionu Morza Bałtyckiego. Prace Komisji Geografii Przemysłu Polskiego Towarzystwa Geograficznego, 33(4), 80-94. doi: 10.24917/20801653.334.5

\section{WSTĘP}

Przedmiotem badań były zakłady przemysłowe zlokalizowane w portach morskich lub powiązane z nimi infrastrukturalnie, które jednak nie były bezpośrednio związane z gospodarką morską - badania nie objęły budownictwa morskiego i okrętowego oraz zakładów przetwórstwa organizmów morskich. Lokalizację analizowanego przemysłu dobrze opisuje klasyczna teoria A. Webera. Postawiono tezę, że pomimo znaczącego postępu w rozwoju transportu i logistyki, w przypadku pewnych branż lokalizacja nadal odgrywa dużą rolę. Dotyczy to zwłaszcza przemysłu surowcochłonnego i mniej zaawansowanego technologicznie. Celem badań było sprawdzenie, jaka jest struktura branżowa tego rodzaju zakładów produkcyjnych, oraz próba oceny roli transportu morskiego w obsłudze poszczególnych zakładów.

Obszar badań to region Morza Bałtyckiego (RMB). Region ten nie jest jednak jednoznacznie zdefiniowany w literaturze. Bezspornie wchodzą w jego skład państwa i ich tereny położone bezpośrednio nad Bałtykiem: Dania, Szwecja, Finlandia, Estonia, Łotwa, Polska, część Niemiec - landy: Meklemburgia-Pomorze Przednie i Szlezwig-Holsztyn, oraz część Federacji Rosyjskiej - obwody: kaliningradzki i leningradzki oraz Sankt Petersburg. Do RMB często zaliczana jest też Norwegia, a także niemieckie landy: Hamburg, Brema i Dolna Saksonia oraz Brandenburgia i Berlin, a ponadto regiony Federacji Rosyjskiej: republika Karelii oraz obwody murmański, pskowski i nowogrodzki. Jedna z najszerszych delimitacji RMB opiera się na obszarze zlewni Morza Bałtyckiego, dlatego znalazła się tam również Białoruś. RMB w części położonej w Unii Europejskiej stanowi jeden z jej makroregionów (European Union Strategy..., 2009; Palmowski, 2017; ESPON, 2018; Nordregio, 2018;). W niniejszym artykule autor jako RMB traktuje dziewięć państw położonych bezpośrednio nad Bałtykiem: Niemcy, Polskę, Litwę, Łotwę, Estonię, Rosję, Finlandię, Szwecję i Danię. Wzięto pod uwagę wszystkie porty w tych państwach położone na wybrzeżu Morza Bałtyckiego i Północnego. Natomiast całkowicie pominięto Norwegię.

Identyfikacji portów i powiązanych z nimi zakładów przemysłowych dokonano na podstawie materiałów kartograficznych: portali Google Maps (2018) i Open Street Map (2018) oraz Baltic Bulk Map 2012. Prześledzono linię brzegową morza w badanych państwach wraz z kanałami - Kilońskim i Trolli, odcinkami rzek stanowiącymi morskie drogi wodne - Wezera, Łaba, Odra i Göta oraz jezioro Wener. Dzięki temu zidentyfikowano nie tylko zakłady położone przy portach handlowych, ale również inne, mające własne małe porty. Uwzględniono zakłady zlokalizowane bezpośrednio przy basenach i nabrzeżach portowych, na terenie zarządzanym przez administrację portową, a także położone w oddaleniu od portów, ale połączone z nimi ciągami transportowymi, 
jak rurociągi lub taśmociągi. Sprawdzono również dostęp tych zakładów do transportu kolejowego (posiadanie bocznicy) jako alternatywnego środka transportu. Następnie wyszukano informacje o zidentyfikowanych zakładach, sprawdzono, czy i jaką działalność prowadzą. Dla części z nich udało się ustalić znaczenie transportu morskiego w obsłudze danego zakładu. Korzystano przy tym z informacji publikowanych przez przedsiębiorstwa, do których te zakłady należały. Na koniec przypisano poszczególne zakłady do branż. Pominięto zakłady przemysłu stoczniowego i przetwórstwa rybnego, które nie były przedmiotem niniejszych badań.

Trudności w identyfikacji i weryfikacji przemysłu dotyczyły przede wszystkim portów rosyjskich. W przypadku obwodu kaliningradzkiego cennym źródłem informacji była publikacja T. Palmowskiego (2013). Natomiast na Łotwie tereny należące do głównych portów handlowych w Rydze, Windawie i Lipawie stanowiły specjalne strefy ekonomiczne i wykraczały daleko poza obszary stricte portowe - w badaniach skupiono się na zakładach położonych bezpośrednio przy nabrzeżach lub terminalach przeładunkowych oraz tych, w przypadku których potwierdzono wykorzystanie transportu morskiego.

\section{UPRZEMYSŁOWIENIE PORTÓW MORSKICH}

Proces uprzemysłowienia portów morskich rozpoczął się już w połowie XIX wieku. Przemysł razem z portami w toku ewolucji doprowadził do powstania dzielnic portowo-przemysłowych. Zlokalizowane tam zakłady korzystały z rozbudowanej na zapleczu portów infrastruktury technicznej, m.in. kolejowej i drogowej, natomiast nie zawsze z sąsiedztwa portu morskiego (Dutkowski, 1983). Na terenie portów morskich odbywa się „różnorodna działalność gospodarcza, w tym przemysłowa i handlowa, która jest pochodną działalności transportowej" (Grzelakowski, 2017: 162). Porty morskie są wielofunkcyjne i silnie zintegrowane z miastem i regionem (Kuźma, Szczepaniak, 1971).

Wśród zakładów przemysłowych funkcjonujących w miastach portowych B. Koselnik (1960) wyróżnił: przemysł portowy zlokalizowany w porcie handlowym lub na terenie odrębnego portu, przeznaczonego wyłącznie dla potrzeb przemysłu oraz przemysł przyportowy, zlokalizowany w mieście portowym i jego otoczeniu. Przemysł portowy można podzielić według kryterium przestrzennego, zwanego też geograficznym, lub według kryterium ekonomicznego - związanego z teorią lokalizacji przemysłu (Piskozub, 1982). Zgodnie z tym drugim podejściem P. Zaremba (1962) wyróżnił trzy kategorie przemysłu w ośrodkach portowych:

- ściśle powiązany z gospodarką morską,

- korzystający bezpośrednio z usług portu, oparty na imporcie lub pracujący na eksport,

- niepowiązany z pracą portu.

Natomiast B. Koselnik (1960) podzielił przemysł portowy na trzy grupy, z których dwie pierwsze związane są ściśle z gospodarką morską, zaś trzecia korzysta jedynie $\mathrm{z}$ transportu morskiego. Podział ten przedstawia się następująco:

- budownictwo okrętowe (stocznie), wcześniej szkutnictwo, a współcześnie także zakłady budowy wielkich konstrukcji, np. morskich elektrowni wiatrowych, mostów, platform wiertniczych; 
- zakłady obsługujące rybołówstwo, np. fabryki lodu łuskowego i mączki rybnej oraz zakłady przetwórstwa ryb i innych organizmów morskich;

- przemysł oparty na przerobie i uszlachetnianiu surowców importowanych drogą morską.

Na powiązania przemysłu z portami morskimi zwracała uwagę E. Adrjanowska (1977), a A. Piskozub (1982: 7) napisał, że „port morski obok funkcji transportowej i handlowej pełni funkcję przemysłową jako miejsce bardziej podatne dla lokalizacji niektórych zakładów przemysłowych". Wśród portów morskich można więc wyróżnić porty przemysłowe. Port przemysłowy to „port przeznaczony wyłącznie na potrzeby przemysłu" (Piskozub, 1982: 10, za: Koselnik, 1960). Autor proponuje rozszerzyć to pojęcie na wszystkie portowe terminale przeładunkowe przeznaczone do obsługi funkcjonujących w ich sąsiedztwie zakładów przemysłowych i często połączonych z nimi systemami transportu wewnętrznego - taśmociągami lub rurociągami. W niniejszym artykule autor przyjął zatem, że są to zarówno samodzielne porty, jak i części portów handlowych, np. pojedyncze nabrzeża lub pirsy przeładunkowe do obsługi danego zakładu przemysłowego. Porty te stanowią ważne ogniwo w przemysłowym łańcuchu produkcyjnym.

Takie porty lub nabrzeża w niektórych przypadkach stanowiły część przedsiębiorstw przemysłowych, a w innych były to porty lub terminale zarządzane przez niezależnych operatorów, których głównymi klientami były zlokalizowane w pobliżu zakłady. Istotna jest tutaj funkcja przeładunku towarów stanowiących surowce do produkcji lub gotowe wyroby wytwarzane w zakładzie przemysłowym zlokalizowanym $\mathrm{w}$ porcie lub $\mathrm{w}$ jego bezpośrednim otoczeniu. $\mathrm{W}$ niniejszym artykule pominięto przemysł stoczniowy produkujący na potrzeby gospodarki morskiej. Jest on w sposób naturalny zrośnięty z działalnością portową.

Czynniki determinujące lokalizację przemysłu w aglomeracjach portowych zostały przedstawione i szczegółowo omówione m.in. przez A. Piskozuba (1982). Opracowanie to nawiązuje do klasycznej teorii A. Webera. W przypadku interesującej nas części przemysłu głównym czynnikiem były koszty transportu. Najniższe koszty transportu występują w punkcie przełamania (przeładunku), a takim miejscem są właśnie porty morskie. L. Kuźma (1968: 26-28) wyróżnił dziewięć grup zakładów przemysłowych najczęściej lokalizowanych w portach morskich:

- rafinerie ropy naftowej i zakłady petrochemiczne,

- przemysł metalurgiczny, w tym: huty, stalownie i walcownie,

- przemysł elektrotechniczny i montownie samochodów,

- przemysł chemiczny,

- olejarnie przerabiające surowce roślinne,

- rafinerie cukru trzcinowego,

- młyny i zakłady przetwórstwa zbóż,

- przędzalnie i zakłady tekstylne,

- przemysł drzewno-papierniczy.

W niniejszym artykule zbadano, na ile wyżej wymienione branże, wyróżnione przez L. Kuźmę (1968), są współcześnie obecne w portach morskich regionu Morza Bałtyckiego.

Rola portów i transportu morskiego w obsłudze zakładów przemysłu portowego jest uwarunkowana m.in.: rodzajem i zakresem działalności prowadzonej przez dany zakład, dostępem do innych środków transportu oraz pochodzeniem surowców lub 
Rycina 1. Schemat łańcucha logistycznego produkcji w przemyśle portowym

A - przygotowanie do transportu morskiego lub wstępna obróbka surowca

B - wytwarzanie półproduktów

C - przetwórstwo końcowe i przygotowanie do dystrybucji

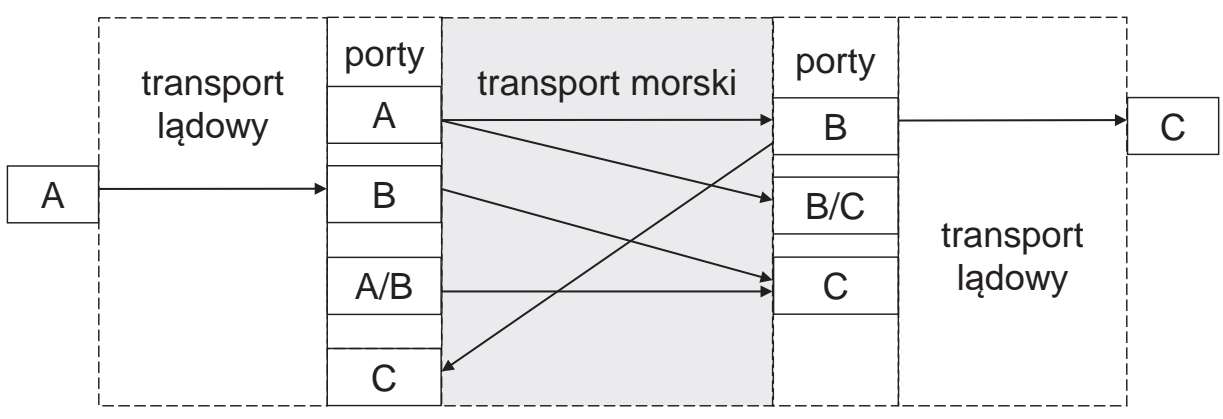

Źródło: opracowanie własne

półproduktów wykorzystywanych do produkcji bądź kierunkami eksportu produkcji. Na rycinie 1 zaprezentowano ogólny schemat łańcucha logistycznego obsługi przemysłu portowego.

Wyróżniono trzy rodzaje działalności przemysłowej prowadzonej w portach morskich: (A) przygotowanie do transportu morskiego lub wstępna obróbka surowca, (B) wytwarzanie półproduktów oraz (C) przetwórstwo końcowe i przygotowanie do dystrybucji. Porty pełnią różną funkcję w łańcuchu produkcji przemysłowej od surowca do produktu końcowego i zależy to w znacznej mierze od technologii i rodzaju przemysłu. W wielu wypadkach port morski jest istotnym ogniwem takiego łańcucha, a lokalizacja portowa danego zakładu najbardziej racjonalna ekonomicznie.

W dobie konteneryzacji, nowoczesnych systemów logistycznych i outsourcingu, pomimo wzrostu przewozów drogą morską, lokalizacja zakładu przemysłowego w porcie straciła obecnie na znaczeniu. Jak pisze J. Boulos (2015), wraz z restrukturyzacją portów część przemysłu przenosi się poza porty i ośrodki portowe. Prawdopodobnie dlatego temat uprzemysłowienia portów morskich w Europie i lokalizacji w nich zakładów spoza branży offshore nie jest obecnie szerzej poruszany w literaturze. Również w publikacjach VASAB tematyka ta była nieobecna (VASAB, 2019). W literaturze podnoszono natomiast kwestie rozwoju samych portów, przemysłu offshore, czyli ściśle związanego z gospodarką morską oraz rewitalizacji terenów portowo-przemysłowych i relacji pomiędzy miastem a portem. W tym ostatnim aspekcie pojawia się wątek interesującego nas przemysłu portowego. Relacje port-miasto i ich ewolucje były przedmiotem licznych badań (przede wszystkim: Bird, 1973; Norcliffe, Basset, Hoare, 1996; Hoyle, 1998). Porty traktowane są w tym kontekście jako kompleksy portowo-przemysłowe (Wiegmans, Louw, 2011; Boulos, 2015). 


\section{PRZEMYSŁ W PORTACH MORSKICH REgIONU MoRZA BAŁTYCKIEGO}

Na terenie RMB w 2017 roku działało 269 morskich portów przeładunkowych (Bocheński, 2019). W sąsiedztwie 112 z nich - co stanowiło 41,6\%, znajdowały się różnego rodzaju zakłady przemysłowe niezwiązane bezpośrednio z produkcją na rzecz gospodarki morskiej. Zidentyfikowano łącznie 146 tego typu przedsiębiorstw. Wyodrębniono dziewięć branż: energetyka cieplna, energetyka jądrowa, petrochemiczna (rafinerie ropy naftowej i produkcja olejów silnikowych), chemiczna (m.in. produkcja nawozów sztucznych), metalurgiczna (huty metali, odlewnie żeliwa, walcownie i inne zakłady obróbki metali), drzewno-papiernicza, mineralna (w tym produkcja kruszyw i cementu), rolno-spożywcza, przetwórstwa tworzyw sztucznych. Do grupy pozostałych zaliczono pojedyncze zakłady reprezentujące inne branże.

Wśród zidentyfikowanych zakładów najwięcej reprezentowało branżę drzewno-papierniczą - 20,5\%. Na drugim miejscu była energetyka cieplna - 15,1\%, a dalej branża mineralna i metalurgiczna - po 13\%, chemiczna razem z przetwórstwem tworzyw sztucznych - 11,6\%, rolno-spożywcza i petrochemiczna - po 9,6\% (tabela 1).

Najwięcej zakładów działało w portach szwedzkich i fińskich (tabela 1, rycina 2). W 17 ośrodkach portowych funkcjonowało po kilka zakładów. Przodowała tu Windawa (Łotwa), na terenie której utworzona została specjalna strefa ekonomiczna. Wpływ bliskości portu morskiego na decyzję lokalizacyjną stwierdzono w przypadku ośmiu z nich, które reprezentowały branże: produkcja tworzyw sztucznych - dwa zakłady, produkcja maszyn i urządzeń - dwa zakłady oraz po jednym z branż: drzewno-papierniczej - produkcja peletu, rolno-spożywczej - produkcja biodiesla, obróbki metali, produkcji konstrukcji i elementów blaszanych oraz produkcji świec. W przypadku pozostałych działających w strefie zakładów główne znaczenie miały inne czynniki, tj. korzyści z oferowanych ulg lub bliskość kooperantów (Ventspils Free Port, 2019). Port ten charakteryzował się jednym z najbardziej zróżnicowanych przemysłów w badanym regionie, a ponadto wszystkie te zakłady otwarto w latach 2004-2017. Innymi portami, gdzie zidentyfikowano więcej zakładów, były: Brunsbüttel (Niemcy) - dwa zakłady chemiczne, zakład produkcji biopaliw oraz asfaltu i mas bitumicznych, Gdańsk - rafineria, zakłady chemiczne i dwa przedsiębiorstwa przetwarzające zboża, Sundsvall - przemysł drzewny, chemiczny i metalurgiczny, Karlshamn - przemysł rolny, mineralny i elektrownia olejowa; Göteborg - trzy rafinerie oraz Szczecin - przemysł chemiczny, papiernia i elektrociepłownia na biomasę. Ponadto w 11 innych portach zidentyfikowano po dwa zakłady, m.in. w Hamburgu działały huty żelaza i aluminium, a w porcie Rostock odbywała się produkcja oleju roślinnego i biopaliw (rycina 1).

W branży drzewno-papierniczej, dominującej w Szwecji i Finlandii, swoje zakłady w portach miały m.in. koncerny Stona Enso - pięć w Szwecji i dwa w Finlandii, oraz SCA - siedem zakładów w Szwecji. Jeden zakład funkcjonował w polskim porcie - papiernia w Szczecinie.

Ważną rolę odgrywał sektor paliwowo-energetyczny, czyli energetyka i petrochemia. Aż 22 elektrownie i elektrociepłownie cieplne oraz pięć atomowych były zlokalizowane w portach morskich i miały własne nabrzeża. Pojedyncze z tych elektrowni były opalane olejem opałowym, odpadami i biomasą, natomiast większość węglem kamiennym. Wśród nich do Ørsted (do 2017 roku Dong Energy) należały cztery elektrownie w Danii, a do Fortum dwie w Finlandii. 


\begin{tabular}{|c|c|c|c|c|c|c|c|c|c|c|c|c|c|c|c|c|c|c|c|c|c|c|}
\hline & әңеұsozod & 6 & 0 & 1 & 1 & 1 & 1 & 1 & 1 & 1 & 1 & 1 & 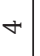 & 1 & 1 & 1 & 1 & -1 & $\dashv$ & - & 1 & \\
\hline & 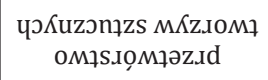 & + & + & 1 & 1 & 1 & 1 & 1 & 1 & 1 & 1 & 1 & $\mathrm{~N}$ & 1 & 1 & 1 & 1 & 1 & $N$ & $\sim$ & I & 离 \\
\hline $\begin{array}{l}\bar{d} \\
\frac{0}{3} \\
\frac{0}{\dot{v}}\end{array}$ & ezoMKẓods-ou[O. & 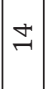 & $\stackrel{m}{\sim}$ & -1 & 1 & 1 & 1 & m & $\sim$ & -1 & + & 1 & -1 & 1 & -1. & $\neg$ & 1 & -1 & + & + & 1 & $\begin{array}{l}\overline{0} \\
\overline{\tilde{J}} \\
\vec{J}\end{array}$ \\
\hline$\stackrel{\bar{N}}{\stackrel{N}{2}}$ & ezว!̣u.ıəฺ̣ded-ouмәZ.ıp & $\stackrel{m}{m}$ & $\stackrel{\rho}{m}$ & 1 & 1 & 1 & 1 & 1 & 1 & 1 & - & 1 & - & 1 & 1 & 1 & 1 & เ & N & & 1 & 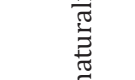 \\
\hline $\begin{array}{l}\frac{y}{\vec{z}} \\
\overline{0} \\
0 \\
\text { t. }\end{array}$ & „еијеләи!ш & $\stackrel{\sigma}{\sigma}$ & $\begin{array}{l}0 \\
-1\end{array}$ & $m$ & $\sigma$ & $\sim$ & $\sim$ & 1 & 1 & 1 & 1 & 1 & 1 & 1 & 1 & 1 & 1 & $r$ & $\exists$ & 이 & -1 & 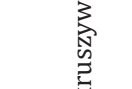 \\
\hline 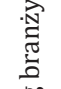 & вuzग!̣шәчગ & $\stackrel{m}{\rightarrow}$ & $a$ & + & 1 & 1 & 1 & $m$ & 1 & $m$ & $m$ & 1 & 1 & 1 & 1 & 1 & 1 & $\sim$ & 几 & + & -1 & $\begin{array}{l}\frac{\pi}{\sqrt{v}} \\
\frac{y}{\partial}\end{array}$ \\
\hline 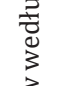 & q euzग!̣̊.ınโеұәш & 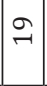 & 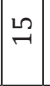 & + & 1 & 1 & 1 & + & 1 & + & -1 & 1 & $\mathrm{~N}$ & -1 & 1 & 1 & 1 & $n$ & + & + & 1 & 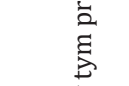 \\
\hline $\begin{array}{l}\frac{\pi}{\sqrt[\pi]{\pi}} \\
\frac{\sqrt[\pi]{\pi}}{\sqrt[n]{n}}\end{array}$ & еєฺшәчәодұәd & 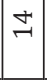 & $\cong$ & $\sim$ & $\sim$ & $\sim$ & 1 & -1 & 1 & -1 & -1 & -1 & -1 & 0 & 1 & 1 & 1 & $m$ & เ & + & -1 & $\stackrel{1}{\check{\Xi}}$ \\
\hline 㦘 & 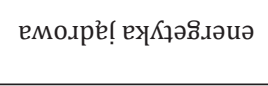 & LO & in & 1 & 1 & 1 & 1 & 1 & 1 & 1 & 1 & 1 & 1 & 1 & 1 & 1 & 1 & $\sim$ & $m$ & $m$ & 1 & \\
\hline & 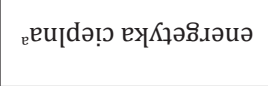 & $\tilde{N}$ & $\vec{N}$ & -1 & $\infty$ & $n$ & $\neg$ & $\neg$ & -1 & 1 & $m$ & 1 & 1 & 1 & 1 & 1 & 1 & 0 & + & + & 1 & 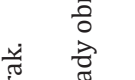 \\
\hline & шәzе. & 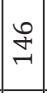 & $\vec{m}$ & $\stackrel{2}{\sim}$ & 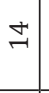 & $\exists$ & $m$ & $\approx$ & $m$ & $\sigma$ & $m$ & -1 & $\exists$ & -1 & -1. & $\neg$ & 1 & $\vec{m}$ & ชิ & ๙ิ) & $m$ & 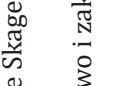 \\
\hline & 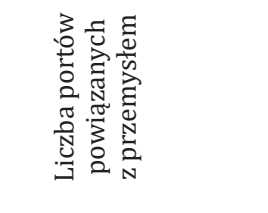 & $\Xi$ & $\begin{array}{l}\tilde{\sigma} \\
- \\
-1\end{array} \mid$ & $\stackrel{1}{\rightarrow}$ & $\rightleftarrows$ & $\exists$ & $m$ & 0 & $\sim$ & +1 & ก & $\neg$ & $m$ & -1 & -1. & -1 & 1 & $\stackrel{\infty}{\sim}$ & ణి & 욘 & $m$ & 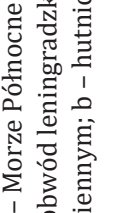 \\
\hline & 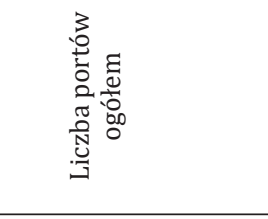 & $\underset{\mathrm{N}}{\stackrel{\sigma}{2}}$ & $\underset{N}{\tilde{N}}$ & $\stackrel{m}{m}$ & กิ & $\mathscr{F}$ & $a$ & मे & $\stackrel{m}{\rightarrow}$ & $\vec{\sim}$ & $\underset{\sim}{\sim}$ & $\sim$ & 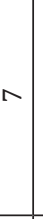 & $\stackrel{\curvearrowright}{\sim}$ & $\underset{\sim}{ \pm}$ & น & $\sigma$ & $\hat{m}$ & $\infty$ & $\infty$ & 0 & 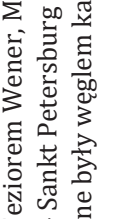 \\
\hline & 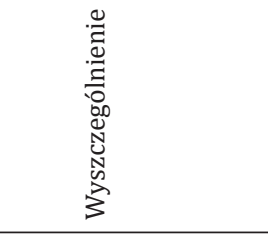 & $\begin{array}{l}\mathbb{J} \\
\mathbb{N} \\
\mathbb{Z} \\
\end{array}$ & $\stackrel{m}{\Sigma}$ & $\stackrel{\Sigma}{\Sigma}$ & 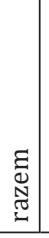 & $\sum$ & 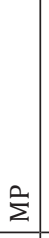 & 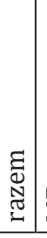 & $\stackrel{m}{\Sigma}$ & $\stackrel{\Sigma}{\Sigma}$ & $\stackrel{\varrho}{\Sigma}$ & $\sum$ & $\stackrel{m}{\Sigma}$ & $\Sigma$ & 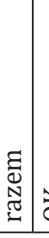 & $\check{\partial}$ & $\stackrel{\overrightarrow{0}}{2}$ & $\stackrel{m}{\Sigma}$ & 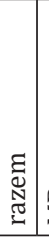 & $\sum_{\Sigma}^{m}$ & $\bar{\Sigma}$ & 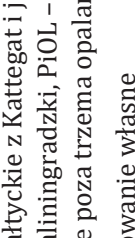 \\
\hline & 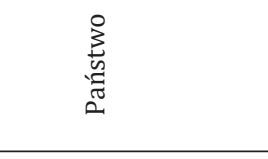 & & 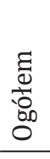 & & & 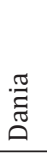 & & & 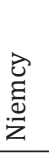 & & $\begin{array}{l}\frac{\pi}{2} \\
\frac{2}{2} \\
0 \\
2\end{array}$ & 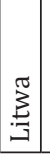 & 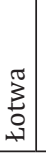 & 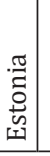 & & $\frac{\pi}{2}$ & & 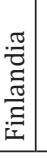 & & 莺 & & 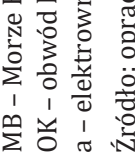 \\
\hline
\end{tabular}


Rycina 2. Zakłady przemysłowe według branż zlokalizowane w portach morskich w regionie Morza Bałtyckiego w 2018 roku

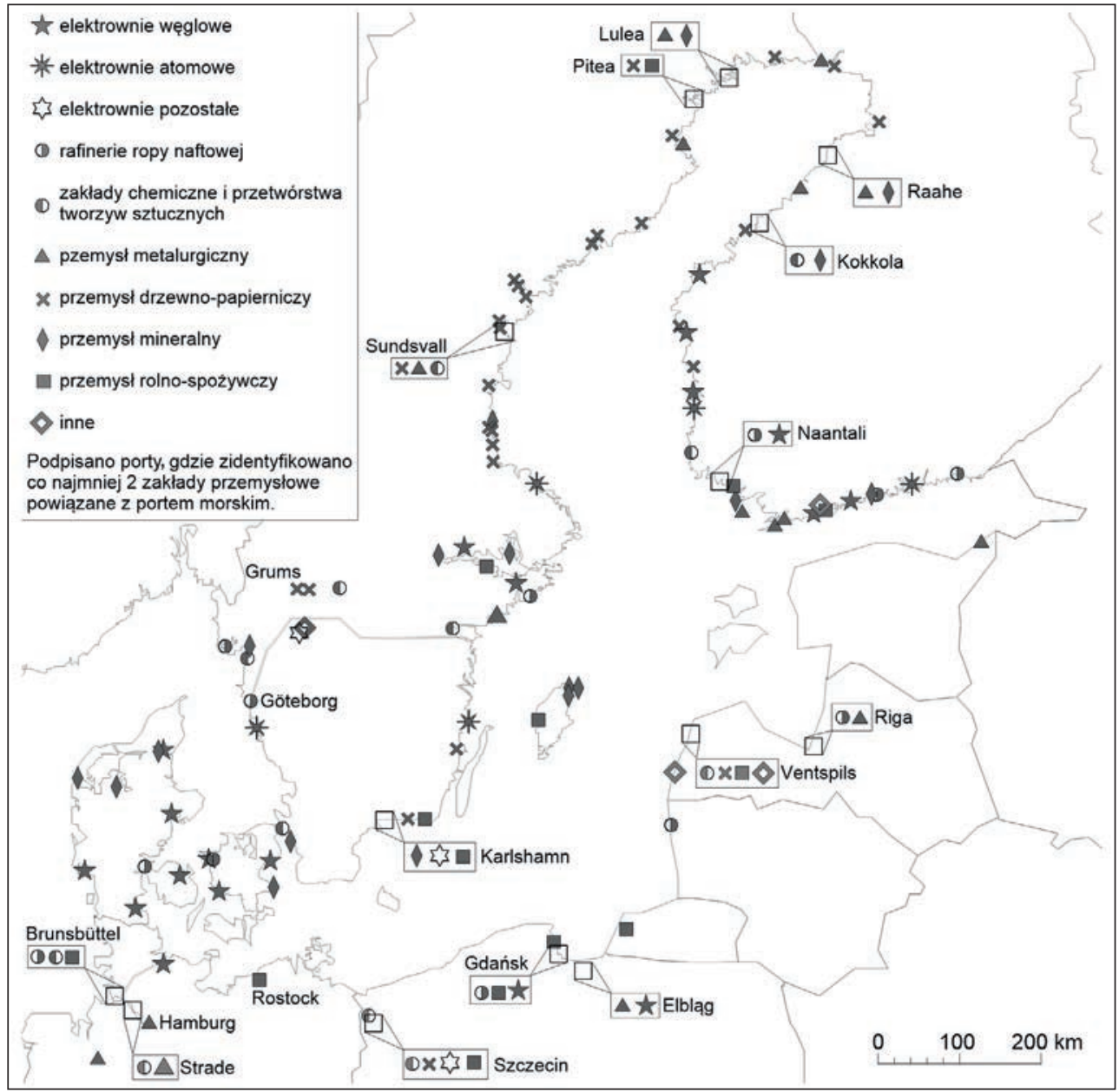

Źródło: opracowanie własne

W portach na badanym obszarze działało także 12 rafinerii, w tym po dwie należące do koncernów Nynas, Neste i Preem oraz po jednej do firm: Statoil, Shell, Orlen, Lotos oraz St1 i STR TecOil. W Gotebörgu w Szwecji działały aż trzy rafinerie. W 2012 roku kanadyjski koncern Alimentation Couche-Tard przejął Statoil i jego rafinerie, a w 2018 roku spółka zmieniła nazwę na Equinor , zaś duńska filia na Equinor Refinning Denmark A/S (Equinor..., 2018). Natomiast rafineria Shell Frederica w Danii w 2016 roku została sprzedana Dansk Olieselskab ApS (Denmark: Shell..., 2016). Duża rafineria z własnym terminalem portowym miała powstać w okolicy Kaliningradu - w pobliżu miejscowości Spaskoje. Natomiast $6 \mathrm{~km}$ dalej, w miejscowości Izewskoje funkcjonował terminal naftowy należący do koncernu Łukoil (Palmowski, 2013). Dostęp do nabrzeża miał także zakład produkcji olejów samochodowych i płynów technicznych Vega Stividors w porcie Ryga na Łotwie oraz zużywający także ropę naftową do produkcji mas bitumicznych zakład Total Bitumen w Brunsbüttel (Niemcy). 
W badanych portach zidentyfikowano 19 zakładów branży mineralnej, większość w Szwecji, a poza tym kilka w Finlandii i Danii. Branżę tę reprezentowało m.in. osiem zakładów koncernu Nordkalk wydobywającego i przetwarzającego wapień (Nordkalk, 2018).

Przemysł chemiczny w badanych portach obejmował kilkanaście zakładów - najwięcej w Szwecji i Niemczech. Zakłady te były zróżnicowane pod względem profilu produkcji:

- sześć zakładów produkujących różnego rodzaju związki chemiczne i komponenty dla innych branż przemysłu, w tym trzy w Niemczech, dwa w Szwecji i jeden w Finlandii;

- cztery zakłady produkujące nawozy sztuczne, w tym trzy w Polsce (Police, Szczecin i Gdańsk) oraz jeden w Finlandii;

- dwa zakłady produkujące m.in. kleje dla przemysłu drzewnego oraz farby i lakiery w Szwecji - oba należące do koncernu Akzo Nobel (Akzo Nobel, 2018);

- zakład produkcji środków chemicznych gospodarstwa domowego Freudenberg w Szwecji;

- cztery zakłady produkcji i przetwórstwa tworzyw sztucznych - po dwa w Szwecji i na Łotwie.

Z branży metalurgicznej w portach zlokalizowane były huty żelaza - w Szwecji, Finlandii i Niemczech, huty aluminium - dwie w Niemczech i jedna w Szwecji oraz walcownie stali i odlewnie żeliwa. Wśród nich trzy zakłady należały do szwedzkiego koncernu SSAB - w tym huty żelaza w Luleå w Szwecji i Raahe w Finlandii (SSAB, 2018). Dwa zakłady w Finlandii w Koverhar i Dragsfjärd funkcjonowały w ramach holenderskiego FN Steel (FN Steel, 2018), zaś niemieckie huty w Hamburgu i Bremen były własnością koncernu ArcelorMittal (ArcelorMittal, 2018). Huty aluminium znajdowały się w portach w Sundsvall - Kubikenborg Aluminium AB, Hamburgu - TRIMET Aluminium SE, Stade - Aluminum oxide Stade GmbH w Stade. Natomiast w Sillmäe (Estonia) usytuowany był zakład produkujący metale rzadkie m.in. niob (NPM Silmet, 2019).

Produkcja rolno-spożywcza, nie licząc zakładów przetwórstwa rybnego, rozwinęła się w kilkunastu badanych portach. Obejmowała ona przede wszystkim produkcję biopaliw i olejów spożywczych oraz przetwórstwo zbóż, m.in. produkcję mąki, kasz i pasz dla zwierząt. Produkcja biopaliw była prowadzona w czterech portach: Norrköping w Szwecji - Lantmännen Agroetanol, Windawie na Łotwie - Bio-Venta, oraz w dwóch niemieckich: Rostock - Biopetrol Rostock GmbH i Brunsbüttel - Mercuria Biofuels. Spożywcze tłuszcze roślinne wytwarzano w zakładach: Power Oil Rostock w Niemczech, AAK Sweden AB w szwedzkim Karlshamnie, Kruszwica w Gdańsku i ZAO Sodrugestvo-Soy w Spaskoje koło Kaliningradu. Zakłady przetwarzające zboża zidentyfikowano w siedmiu portach. W Szwecji należały one do grupy Lantmännen - zakłady w: Klintehamn, Strängnäs, Norrköping i Helsingborgu (Lantmännen, 2018). W portach Rostock i Gdańsk znajdowały się słodownie grupy Malteurop (Groupe..., 2018). W polskim porcie Gdynia funkcjonowała łuszczarnia ryżu Rol-Ryż sp. z o.o. Natomiast w innych portach, gdzie przeładowywane było zboże, znajdowały się jedynie elewatory do jego przechowywania. Ponadto w fińskim porcie Kantvik działała cukrownia - Suomen Sokeri Oy.

Większość zakładów, które można przypisać do grupy pozostałych, znajdowało się na Łotwie. Z terenem portu Lipawa sąsiadował przemysł tekstylny - zakład Lauma Fabrics (Liepaja Special..., 2019). Trudno jednak ocenić, na ile bliskość portu morskiego 
miała wpływ na jego lokalizację. Natomiast w Windawie działały zakłady produkujące maszyny i urządzenia oraz konstrukcje i obiekty przemysłowe (Ventspils Free Port, 2019). Ponadto zaliczono do tej grupy zakłady produkujące materiały izolacyjne dla budownictwa w Szwecji oraz kable energetyczne i telekomunikacyjne w Finlandii.

Gdyby wziąć pod uwagę całe ośrodki portowe, zlokalizowanych tam zakładów przemysłowych byłoby znacznie więcej. Należy jednak pamiętać, że w niniejszych badaniach uwzględniono jedynie te, które były ściśle powiązane z portami poprzez swoją lokalizację lub infrastrukturę - np. rafinerie w Gdańsku i Możejkach położone były w oddaleniu od portów, jednak połączone rurociągami z terminalami przeładunkowymi.

W kontekście powyższych wyników warto przyjrzeć się strukturze przemysłu i specjalizacji przemysłowej w krajach RMB. Najbardziej zróżnicowane pod względem struktury specjalizacji przemysłu były Niemcy i Polska. Przemysł drzewno-papierniczy, który był tak licznie reprezentowany w badanych portach, był główną gałęzią w Finlandii oraz miał istotne znaczenie w Szwecji, Polsce i na Litwie (Russu, 2015). Ważną rolę, niezależnie od specjalizacji przemysłowej, w części z badanych krajów odgrywała energetyka cieplna. Należy jednak zaznaczyć, że Dania i Finlandia do 2030 roku planują całkowite wycofanie się z energetyki węglowej (Denmark to be..., 2017) - w portach w tych krajach działało łącznie 14 elektrowni cieplnych.

\section{ROLA TRANSPORTU MORSKIEGO W OBSŁUDZE WYBRANYCH ZAKŁADÓW PRZEMYSŁOWYCH}

Należy zwrócić uwagę, że dla niektórych zakładów transport morski stanowił podstawę funkcjonowania, jako najważniejszy środek transportu w łańcuchu logistycznym. Część zakładów nie miała bowiem dostępu do kolei, zatem potencjalnie transport morski miał dla nich istotne znaczenie. Zidentyfikowano 42 takie zakłady - do grupy tej należało:

- 10 zakładów przemysłu mineralnego, produkujących kruszywa lub cement: pięć w Szwecji (Elleholm, Slite, Bunge, Storugns, Balsta), trzy w Danii (Thyboron, Skive, Store Heddinge) i dwa w Finlandii (Sorpo, Kalkstrand Sipoo);

- 11 elektrowni węglowych, w tym osiem w Danii (Esbjerg, Avedorevarket, Stigsnasvarket, Asnaesaerket, Odense, Enstedvarket, Studstrupvarket, Nordjyllandsvarket) i trzy w Finlandii (Helsinki, Inko, Kristiinankaupunki);

- siedem zakładów przemysłu drzewno-papierniczego - sześć w Szwecji (Kage, Rundvik, Bolstabruk, Utansjö, Iggesund, Ronnebyhamn) i jeden w Finlandii (Krookka);

- pięć elektrowni atomowych, w tym trzy szwedzkie i dwie fińskie;

- trzy rafinerie: Brofjorden Preem Lyseki i Nynas, Nynäshamn w Szwecji oraz Statoil-haven koło Kalundgborg w Danii;

- przemysł rolno-spożywczy, w tym dwa zakłady przetwórstwa zbóż w Szwecji należący do Lantmännen w Klintehamn i do AB Strängnäs Valskvarn w Strängnäs oraz cukrownia w fińskim Kantvik - Suomen Sokeri Oy Porkkala, należąca do koncernu Nordzucker Group;

- dwa zakłady metalurgiczne w Finlandii: Ruukki Engineering Oy w Rahja, Fnsteel Dalwire Oy Ab w Dragsfjärd;

- zakład produkcji kabli Prysmian Finland Oy w fińskim Batvik. 
Natomiast część zakładów, pomimo własnego nabrzeża lub lokalizacji bezpośrednio przy porcie, przestała korzystać z transportu wodnego lub wykorzystywała go sporadycznie. Wykorzystanie portów i transportu morskiego uwarunkowane było przede wszystkim wielkością generowanych przewozów i ich kierunkami.

Porty przy elektrowniach węglowych w Danii i Finlandii przeładowywały rocznie ponad 0,5 mln t węgla (Baltic Bulk Map 2012). Kraje skandynawskie nie miały złóż węgla i surowiec ten zarówno dla energetyki, jak i dla hutnictwa dostarczany był przede wszystkim drogą morską, zwłaszcza że część elektrowni nie miała dostępu do kolei. Zdecydowana większość elektrowni węglowych w Danii i Finlandii położona była na wybrzeżu i korzystała z transportu morskiego.

Dużymi przeładunkami charakteryzowały się porty przy rafineriach. W 2015 roku w pierwszej dziesiątce portów bałtyckich pod względem przeładunku towarów masowych ciekłych znalazły się cztery ośrodki portowe, w których działały rafinerie, w tym dwa porty funkcjonujące wyłącznie na potrzeby zlokalizowanych tam zakładów: Sköldvik w Finlandii i Brofjorden w Szwecji oraz duże porty handlowe z przemysłem rafineryjnym: Göteborg i Gdańsk (Klopott, b.d.). W Sköldvik i Brofjorden przeładowywano rocznie ponad 20 mln t ropy i jej przetworów, w duńskim Statoil-Havnen koło Kalundborga i litewskiej Butyndze - również funkcjonujących na potrzeby tamtejszych rafinerii - było to ponad $5 \mathrm{mln}$ t (Baltic Bulk Map 2012), a w Gdańsku około $3 \mathrm{mln}$ t produktów rafinerii Lotos (Jamroż, 2013). Najmniejszy w tej grupie, choć o znacznych przeładunkach, był port Butynga na Litwie. Powstał w latach dziewięćdziesiątych XX wieku i obejmuje jedno wysunięte w morze stanowisko cumownicze. Port ten umożliwia import ropy na potrzeby rafinerii w Możejkach i tym samym uniezależnienie Litwy od dostaw tego surowca z Rosji (Orlen Lietuva, 2018).

Znaczne przeładunki miały miejsce również w portach przy kopalniach kruszyw i cementowniach. W duńskim Aalborg Portland przeładowywano rocznie ponad $1 \mathrm{mln} t$ cementu, podobnie w szwedzkich portach Slite i Storugns na Gotlandii (Baltic Bulk Map 2012).

Duże masy towarowe przeładowywane były także w portach w ośrodkach przemysłu metalurgicznego w Szwecji i Finlandii: Luleå, Tornio, Raahe i Oxelösund, do których drogą morską dostarczano przede wszystkim węgiel i koks.

Również przemysł chemiczny wykorzystywał transport morski, choć zlokalizowane w portach zakłady miały w większości dostęp do kolei. Przykładem był port w Policach, który przeładowywał na potrzeby tamtejszych zakładów chemicznych ponad 1,5 mln t rocznie. Przeładunki odbywały się w obu kierunkach - były to zarówno surowce do produkcji, jak i gotowe produkty.

Transportem morskim przewożono znaczne ilości ziaren zbóż i nasion roślin oleistych. W pięciu portach, w których działały zakłady przetwórstwa zbóż i produkcji olejów roślinnych, przeładowywano ponad 0,5 mln t zboża rocznie - były to Norrköping, Helsingborg, Rostock, Gdynia i Gdańsk (Baltic Bulk Map 2012). Portowe terminale zbożowe i powiązane z nimi zakłady miały równocześnie dostęp do kolei. Zakłady, np. młyny, przerabiały nie tylko surowce importowane, ale także krajowe na rynek wewnętrzny.

Nad morzem zlokalizowano elektrownie jądrowe w Szwecji: Ringhals, Forsmark i Öskarshamn na półwyspie Simpevarp oraz w Finlandii: Loviisa i Olkiluoto. Transport zarówno świeżego, jak i zużytego paliwa odbywał się do nich drogą morską. Szwecja dysponowała co prawda niewielkimi złożami uranu, jednak ich eksploatacja okazała się 
nieopłacalna. Nadmorska lokalizacja elektrowni umożliwiała ponadto wykorzystanie wody morskiej do chłodzenia (Jezierski, 2004). Także w Niemczech na badanym obszarze funkcjonowały dwie takie elektrownie z własnymi nabrzeżami, ale dodatkowo miały własne bocznice kolejowe. Obie elektrownie zostały jednak wyłączone - Greifswald-Lubmin w 1995 roku i Stade w 2003 roku (Niemcy rezygnują..., 2003). W Lubminie przy dawnej elektrowni jądrowej na ląd wychodzi gazociąg Nord Stream, a w 2013 roku uruchomiono elektrownię gazową (Balcewicz, 2015).

Główne porty łotewskie funkcjonowały w połączeniu ze specjalnymi strefami ekonomicznymi. Zakłady zidentyfikowane w Windawie korzystały ze zlokalizowanych w porcie terminali przeładunkowych, zwłaszcza z VK Terminal, obsługującego chemikalia, biodiesel i produkty naftowe (VK Terminal, 2019). Znaczna część produkcji tamtejszych zakładów była eksportowana do Skandynawii i Europy Zachodniej (Ventspils Free Port, 2019). Ze względu na położenie Łotwy i niewielki rynek wewnętrzny lokalizacja w porcie znacznie ułatwiała eksport.

\section{PODSUMOWANIE I WNIOSKI}

Z około 270 portów przeładunkowych w regionie Morza Bałtyckiego ponad 2/5 posiadało rozwinięty przemysł niezwiązany bezpośrednio z gospodarką morską. Najwięcej było ich w Finlandii - 76\% portów tego kraju i Szwecji - 60\%. Na Łotwie analizowany przemysł występował w trzech głównych, tj. 43\% wszystkich portów w tym kraju, a w Polsce w pięciu, czyli ponad 1/3 badanych.

Czynnikiem determinującym lokalizację przemysłu w ośrodkach portowych były przede wszystkim korzyści wynikające z obniżenia kosztów i ułatwienia transportu surowców i gotowych produktów. Rosja, a wcześniej ZSRR, miała bogatą bazę surowcową w głębi kraju i tam też koncentrował się przemysł. Porty morskie służyły głównie do eksportu surowców i zasadniczo nie miały rozwiniętego przemysłu poza stoczniami. Uprzemysłowienie portów łotewskich, zwłaszcza Windawy, nastąpiło po wejściu tego kraju do Unii Europejskiej. Powstało tam wiele zakładów nakierowanych na produkcję eksportową do Skandynawii i Europy Zachodniej. Natomiast w krajach skandynawskich lokalizacja przemysłu w portach ułatwiała import surowców, przede wszystkim energetycznych, tj. węgla, koksu i ropy naftowej, oraz eksport gotowych produktów, np. cementu, wyrobów hutniczych i celulozy.

W Szwecji i Finlandii rozmieszczenie portów powiązanych z przemysłem było stosunkowo równomierne i w większości z nich zidentyfikowano pojedyncze zakłady. Podobnie w Danii, choć tu widoczne były dysproporcje pomiędzy wybrzeżem Bałtyku i Morza Północnego, co wynikało z rozmieszczenia portów w tym kraju. Na Łotwie przemysł zlokalizowany był $\mathrm{w}$ trzech największych portach. W pozostałych krajach RMB widoczna była koncentracja przemysłu w mniejszej liczbie portów. W Niemczech badany przemysł koncentrował się w rejonie ujściowego odcinka Łaby i na zachodnim końcu Kanału Kilońskiego. Polskie porty na tle innych krajów RMB były stosunkowo dobrze uprzemysłowione. Zróżnicowany przemysł portowy koncentrował się zwłaszcza w Gdańsku i Szczecinie. Funkcjonował także jeden port o typowo przemysłowym charakterze - Police, należący do zakładów chemicznych. Natomiast porty środkowego wybrzeża były pozbawione przemysłu niezwiązanego ściśle z gospodarką morską. Na Łotwie badany przemysł umiejscowił się w największych portach. 
W strukturze zidentyfikowanych zakładów największą grupę stanowił przemysł drzewno-papierniczy - ulokowany w Szwecji i Finlandii. W badanych portach działały także liczne zakłady z branży energetycznej, mineralnej i metalurgicznej. Spośród rodzajów zakładów funkcjonujących w portach morskich wyróżnionych przez L. Kuźmę (1968) w portach regionu Morza Bałtyckiego w minimalnym stopniu reprezentowany był przemysł tekstylny i cukrowniczy. Przemysł tekstylny zidentyfikowano jedynie w sąsiedztwie jednego z portów łotewskich, zaś przemysł cukrowniczy funkcjonował w jednym porcie w Finlandii. W badanych portach znalazły się natomiast liczne elektrownie i cementownie.

Transport morski miał kluczowe znaczenie dla sektora paliwowo-energetycznego. W badanych portach funkcjonowało wiele zakładów, dla których transport morski stanowił jedyną lub główną drogę dostaw surowców do produkcji, np. dla 11 z 22 elektrowni, trzech z 12 rafinerii, lub do eksportu produktów: sześciu z 28 zakładów przemysłu drzewno-papierniczego oraz 10 z 19 zakładów przemysłu mineralnego. Nad morzem zlokalizowane były wszystkie szwedzkie i fińskie elektrownie atomowe - obsługiwane również wyłącznie drogą morską.

Żeglugą morską na potrzeby zidentyfikowanych zakładów przewożono przede wszystkim: ropę naftową i jej przetwory, węgiel i koks, kruszywa i cement, drewno, celulozę oraz paliwo jądrowe. Inną, liczącą się grupą towarów transportowanych tą drogą, były ziarna zbóż i nasiona roślin oleistych.

Można wyodrębnić dwa typy portów przeznaczonych do obsługi przemysłu:

- samodzielne porty - wyodrębnione administracyjnie i należące do zakładów przemysłowych, np.: Brofjorden, Sköldvik, Butinge, Statoil-Havnen, Police, Aalborg Portland;

- części portów handlowych (pojedyncze terminale) do obsługi danego zakładu przemysłowego zlokalizowanego w porcie lub jego sąsiedztwie - mogą one należeć do danego zakładu przemysłowego lub do niezależnego operatora, z którym dany zakład zawarł umowę na obsługę przeładunków, np. Nabrzeże Chemików w porcie Gdańsk - GZNF Fosfory, VK Terminal w porcie Windawa - Bio-Venta.

Portowe terminale przeładunkowe do obsługi funkcjonujących w ich sąsiedztwie zakładów przemysłowych były najczęściej połączone z nimi systemem transportu wewnętrznego - z reguły taśmociągami lub rurociągami.

\section{Literatura \\ References}

Adrjanowska, E. (1977). Morze jako czynnik lokalizacji przemysłu. Zeszyty Naukowe Wydziału Biologii i Nauk o Ziemi Uniwersytetu Gdańskiego, Geografia, 7.

Akzo Nobel (2018, 1 sierpnia). Pozyskano z https://www.akzonobel.com/

ArcelorMittal (2018, 1 października). Pozyskano z https://germany.arcelormittal.com/

Balcewicz, J. (2015). W cieniu dawnej elektrowni jądrowej, tam gdzie Gazociąg Północy wychodzi z morza na ląd. Energia Gigawat, 7. Pozyskano z http://gigawat.info/artykul/items/w-cieniu-dawnej-elektrowni-jadrowej-tam-gdzie-gazociag-polnocy-wychodzi-z-morza-na-lad. html

Baltic Bulk Map 2012 (b.d.). Baltic Transport Journal, Gdynia: Baltic Press.

Bird, J., (1973). Centrality and Cities. Routledge Taylor and Francis Group: London, 1-23.

Bocheński, T. (2019). Porty morskie w krajach nadbałtyckich. W: A. Cedro (red.). Polska geografia morza. Przyrodnicze i społeczno-ekonomiczne badania morza i obszarów nadmorskich. Szczecin: Volumina, 125-146. 
Boulos, J. (2015). Sustainable Development of Coastal Cities-Proposal of a Modelling Framework to Achieve Sustainable City-Port Connectivity. Procedia - Social and Behavioral Sciences, 216, 974-985. doi: 10.1016/j.sbspro.2015.12.094

Denmark to be Coal-Free by 2030 (2017, 16 listopada), State of Green. Pozyskano z https://stateofgreen.com/en/partners/state-of-green/news/denmark-to-be-coal-free-by-2030/

Denmark: Shell Frederica Refinery Sold to Dansk Olieselskab ApS (2016, 16 września). Pozyskano $\mathrm{z}$ https://www.petrolworld.com/europe/item/25883-denmark-shell-frederica-refinery-sold-to-dansk-olieselskab-aps

Dutkowski, M. (1983). Polaryzacja przestrzeni miejskiej aglomeracji gdańskiej. Maszynopis rozprawy doktorskiej. Gdynia: Wydział Biologii i Nauk o Ziemi Uniwersytetu Gdańskiego.

Equinor Refinning Denmark A/S (2018, 1 października). Pozyskano z https://www.equinor. com/en/where-we-are/denmark.html

ESPON Baltic Sea Region (2018, 28 listopada). Pozyskano z http://bsr.espon.eu/opencms/ opencms/Gallery/BSR-Background-Maps.html

European Union Strategy for the Baltic Sea Region (2009, 10 czerwca). Communication from the Commission to the European Parliament, The Council, The European Economic and Social Committee and the Committee of the Regions, COM(2009) 248 final, Brussels.

FN Steel (2018, 1 sierpnia). Pozyskano z https://www.fnsteel.eu/

Google Maps (2018, 2 stycznia). Pozyskano z https://www.google.pl

Groupe Vivescia Malteurop (2018, 1 października). Pozyskano z https://pl.malteurop.com/

Grzelakowski, A.S. (2017). Porty morskie jako przedmiot badań w naukach ekonomicznych. Problemy Transportu i Logistyki, 1(37), 161-169. doi: 10.18276/ptl.2017.37-26

Hoyle, B.S. (1998). Citiesand ports: conceptsand issues. Journal of Vegueta, 3, 263-278.

Jamroż, M. (2013, 17 czerwca). Historia gdańskiego Lotosu. Dodatek do „Gazety Wyborczej”.

Jezierski, G. (2004, 26 maja). Energetyka jądrowa w Szwecji. Najlepsza w surowym klimacie. Gigawat Energia. Pozyskano z http://gigawat.net.pl/article/articleprint/360/-1/41/

Klopott, M. (b.d.). The Baltic Sea as a model region for green ports and maritime transport. GdyniaTallin: Baltic Port Organization.

Koselnik, B. (1960). Niektóre problemy industrializacji polskich portów morskich. Szczecin, 4-5, 48-51.

Kuźma, L. (1968). Ekonomika portów morskich. Sopot: Wydawnictwo Wyższej Szkoły Ekonomicznej.

Kuźma, L., Sczepaniak, T. (1971). Porty morskie. Gdańsk: Wydawnictwo Morskie.

Lantmännen (2018, 1 października). Pozyskano z https://lantmannen.com/om- lantmannen/ organization-och-verksamhet/

Liepaja Special Economic Zone (2019, 1 czerwca). Pozyskano z https://liepaja-sez.lv/en/lsez/ teritorija

Niemcy rezygnuja z elektrowni atomowych (2003, 15 listopada). Pozyskano z https://www. rmf24.pl/nauka/news-niemcy-rezygnuja-z-elektrowni-atomowych,nId,109685

Norcliffe, G., Basset, K., Hoare, T. (1996). The emergence of postmodernism on the urban waterfront. Geographical perspectives on changing relationships. Journal of Transport Geography, $4(2), 123-134$.

Nordkalk (2018, 1 sierpnia). Pozyskano z http://www.nordkalk.pl/kontakt/lokalizacje/Ruotsi/

Nordregio (2018, 28 listopada). Pozyskano z http://archive.nordregio.se/en/Metameny/AboutNordregio/Modules-About-Nordregio/Geographical-scope-we-cover/Baltic-Sea-Region/ index.html

NPM Silmet (2019, 1 czerwca). City of Sillmäe. Pozyskano z http://www.sillmae.ee/web/eng/ molycorp-silmet

Open Street Map (2018, 2 stycznia). Pozyskano z https://www.openstreetmap.org

Orlen Lietuva (2018, 1 października). Pozyskano z https://www.orlenlietuva.lt/EN/Company/ Ol/Pages/Terminal-and-Pipelines.aspx

Palmowski, T. (2013). Kaliningrad - szansa czy zagrożenie dla Europy Bałtyckiej. Gdańsk-Pelplin: Uniwersytet Gdański i Wydawnictwo Bernardinum.

Palmowski, T. (2017). Baltic Europe - 40 years of integration. Studia Regionalia, 52, 41-57. 
Piskozub, A. (1982). Przesłanki teoretyczne lokalizacji przemysłu w aglomeracjach portowych. W: A. Piskozub (red.). Przemysł w aglomeracjach portowych Polski. Gdańsk: Wydawnictwo Morskie, 9-52.

Russu, C. (2015). Industrial specialization of the European Union member countries. Economic Insights - Trends and Challenges, IV(LXVII), 63-73.

SSAB (2018, 1 sierpnia). Pozyskano z https://www.ssab.com/company/about-ssab/our-business/ssab-europe

Wiegmans, B.W., Louw, E. (2011). Changing port-city relations at Amsterdam: A new phase at the interface? Journal of Transport Geography, 19, 575-583.

VASAB (2019, 1 czerwca). Pozyskano z https://vasab.org/

Ventspils Free Port (2019, 1 czerwca). Pozyskano z http://www.portofventspils.lv/en/invest-inventspils/industrial-clients/

VK Terminal (2019, 1 czerwca). Pozyskano z http://www.vktranzits.lv/en/venta/services/

Zaremba, P. (1962). Urbanistyka miast portowych. Szczecin.

Tadeusz Bocheński, dr, adiunkt w Instytucie Gospodarki Przestrzennej i Geografii Społeczno-Ekonomicznej Uniwersytetu Szczecińskiego. Specjalizuje się w geografii transportu. Prowadzi badania z zakresu: funkcjonowania kolei i transportu intermodalnego, funkcjonowania portów morskich oraz powiązań między przemysłem a koleją i portami morskimi. Obszar badań obejmuje przede wszystkim Polskę, Europę Środkowo-Wschodnią i region Morza Bałtyckiego. W polu jego zainteresowań znajduje się również delimitacja regionów funkcjonalnych w Polsce.

Tadeusz Bocheński, PhD, assistant professor in the Institute of Spatial Management and Socio-Economic Geography of the University of Szczecin, Poland. He specialises in transport geography. He conducts research in the fields of: railway operation and intermodal transport, operation of seaports and links between industry and railways and sea ports. The research area mainly covers Poland, Central and Eastern Europe and the Baltic Sea Region. His field of interest also includes the delimitation of functional regions in Poland.

ORCID: 0000-0001-6172-7914

\section{Adres/address:}

Uniwersytet Szczeciński

Instytut Gospodarki Przestrzennej i Geografii Społeczno-Ekonomicznej

ul. Mickiewicza 18, 70-383 Szczecin, Polska

e-mail: tadeusz.bochenski@usz.edu.pl 